1 Comparison of antioxidant activity between cyanidin-3-O-glucoside

2

3

4

\section{cell cultures}

1 Zhejiang Provincial Key Laboratory of Biometrology and Inspection and Quarantine, China Jiliang University, Hangzhou 310018, China;

2 Ningbo Academy of Inspection and Quarantine, ningbo yingyi road No.66 A building room 518, nignbo 315012, China;

3 Zhejiang Provincial Center for Disease Control and Prevention, 3399 Binsheng Road, Hangzhou 310051, China;

4 Chiatai Qingchunbao Pharmaceutical Co., LTD , NO. 551 Xixi Road, Hangzhou 310023, China;

5 Food Science Institute, Zhejiang Academy of Agricultural Sciences, 298 Desheng Road, Hangzhou 310021, China;

* Correspondence: Rongfaguan@163.com; Tel.: +86-571-876-76269; Fax: $+86-571-869-1449$

$\dagger$ These authors contributed equally to this work. 
43

\section{ABSTRACT}

The $2 \mathrm{D}$ cell culture is the predominant in vitro model for numerous studies. However, 2D cell cultures may not accurately reflect the functions of three-dimensional (3D) tissues, which have extensive cell-cell and cell-matrix interactions; thus, using 2D cell cultures may lead to inaccurate experimental results. Therefore, to obtain adequate and detailed information about the antioxidant activity of cyanidin-3-O-glucoside $(\mathrm{C} 3 \mathrm{G})$ and $\mathrm{C} 3 \mathrm{G}$ liposomes in the 2D and $3 \mathrm{D}$ cell culture models, we used in this study $\mathrm{H}_{2} \mathrm{O}_{2}$ to construct the cell damage model and assess the antioxidant activity of $\mathrm{C} 3 \mathrm{G}$ and $\mathrm{C} 3 \mathrm{G}$ liposomes on Caco-2 cells cultured in the $3 \mathrm{D}$ model. We also measured the cell viability, cell morphology, and activity of glutathione (GSH), superoxide dismutase (SOD), total antioxidant capacity (T-AOC), and malondialdehyde (MDA) content of Caco-2 cells treated with $\mathrm{H}_{2} \mathrm{O}_{2}, \mathrm{C} 3 \mathrm{G}$, and C3G liposomes. Results showed that cells cultured in the 3D culture model formed a $3 \mathrm{D}$ structure and tight spheroids and showed increased cell activity and $\mathrm{IC}_{50}$. The $\mathrm{C} 3 \mathrm{G}$ and $\mathrm{C} 3 \mathrm{G}$ liposomes can enhance the activity of GSH, SOD, and T-AOC but decrease the MDA content. At the same time, the effect was more obvious in the 3D cell culture model than in the cells cultured in the 2D model. This study revealed that the results obtained from the $2 \mathrm{D}$ cell model may be inaccurate compared with the results obtained from the 3D cell model. A realistic mechanism study of antioxidant activity of $\mathrm{C} 3 \mathrm{G}$ and $\mathrm{C} 3 \mathrm{G}$ liposomes in the 3D cell model, which acts as an intermediate stage bridging the in vitro $2 \mathrm{D}$ and in vivo models, was observed.

Keywords: 3D cell culture; C3G; C3G liposomes; Antioxidant activity; Caco-2 cell 
65

\section{Introduction}

Anthocyanins are water-soluble vacuolar pigments found in most species in the plant kingdom and are responsible for the red, purple, and blue colors of many fruits, vegetables, and flowers ${ }^{1,2}$. Anthocyanins exhibit potential free radical-scavenging activities that prevent low-density lipoprotein oxidation and positively affect chronic gut inflammatory diseases, obesity, and inflammation ${ }^{3-5}$. Moreover, cyanidin-3-O-glucoside ( $\mathrm{C} 3 \mathrm{G})$, which is an anthocyanin with a high percentage and belongs to the flavonoid family and commonly present in human diet, exhibits antiinflammatory and antioxidant effects ${ }^{6-8}$. Some studies have showed that $\mathrm{C} 3 \mathrm{G}$ protects from the adverse effects of radiation, controls the key aspects of tumorigenesis, inhibits proliferation, induces apoptosis of cancer cells, reduces oxidative stress, fights $\mathrm{H}_{2} \mathrm{O}_{2}$-induced oxidative stress in human embryonic kidney cells, induces cell apoptosis and inhibit cell migration ${ }^{9-15}$.

Liposomes are vesicles, wherein the small aqueous volumes are surrounded by bilayer membranes that are normally composed of phospholipids ${ }^{16,17}$. Liposomes can enhance the stability and bioavailability of encapsulated materials by protecting them from external environment factors, making them ideal candidates for drug delivery and important in food systems. ${ }^{18-21}$.

The two-dimensional (2D) monolayer cell models have low anatomical and physiological relevance and remain the predominant in vitro model for numerous studies $^{22,23}$. However, some disadvantages exist in the use of the $2 \mathrm{D}$ monolayer cell model in vitro in some studies. Growing concerns have been demonstrating that 
87 monolayer and monotypic (2D) cellular screening assays may not effectively reproduce the response of a three-dimensional (3D) solid tumor to pharmacological compounds $^{24,25}$. In cancer research, the limitations of the 2D models are considered one major reason for the approximately $95 \%$ of potential anticancer drugs failures in clinical trials ${ }^{26}$.

The 3D spheroid cell culture systems are providing new insights into tumor biology and also in differentiation, tissue organization, and homeostasis ${ }^{27,28}$. Cells in in vitro $3 \mathrm{D}$ culture systems are in league with their counterparts in vivo compared with cells grown as 2D monolayers, wherein 2D monolayer cells also exhibit altered cell cycle durations, morphologies, susceptibility to drugs, metabolism, and gene and protein expression levels ${ }^{29,30}$. Cells cultured as 3D models exhibit features that are close to the complex in vivo conditions ${ }^{31}$ and have been proven realistic for translating the study findings for in vivo applications; moreover, culturing cell lines as $3 \mathrm{D}$ models induces them to behave a step closer to the natural conditions ${ }^{32,33}$. The $3 \mathrm{D}$ models also can help investigate the interplay between different physiological conditions (oxygen or nutrient deprivation), irradiation, or other physical and chemical stimuli $^{34}$.We used liposome technology because liposomes can protect embedding materials and thus improve the effectiveness and stability of $\mathrm{C} 3 \mathrm{G}$, which could be used as a carrier.

Therefore, the objectives of this study were to compare the antioxidant activity of $\mathrm{C} 3 \mathrm{G}$ and $\mathrm{C} 3 \mathrm{G}$ liposomes by assessing the cellular viability in Caco-2 cells cultured in $2 \mathrm{D}$ and $3 \mathrm{D}$ conditions. We compared the antioxidant activity via the assay of 
109

110

111

112

113

114

115

116

117

118

119

120

121

122

123

124

126

127

128

129

130

glutathione (GSH), superoxide dismutase (SOD), malondialdehyde (MDA), and total antioxidant capacity (T-AOC).

\section{Materials and methods}

\subsection{Materials}

The Caco-2 cells (CBCAS, Shanghai, China) , Cyanidin-3-glucoside (C3G) was purchased from Chengdu Biopurify Phytochemicals Ltd (Chengdu,China). Phosphatidylcholine (PC) and cholesterol $(\mathrm{CH})$ were purchased from Beijing Shuangxuan Microorganism Co. Ltd (Beijing, China). Chloroform and diethyl ether were obtained from Hangzhou Jiachen Chemical Company (Hangzhou, China). All other chemicals were of reagent grade. The water used for all experiments was deionized water.

\subsection{Methods}

\subsubsection{Preparation of C3G liposomes}

C3G liposomes were prepared by reverse-phase evaporation method ${ }^{35,} 36$. Phosphatidylcholine and cholesterol were dissolved in chloroform-diethyl ether( $\mathrm{W}_{\mathrm{PC}}$ : $\left.\mathrm{W}_{\mathrm{CH}}=2.87: 1\right) . \mathrm{C} 3 \mathrm{G}$ was dissolved in phosphate-buffered saline (PBS) (0.20 M, pH 7.4). Then, the organic phase was homogenized with the aqueous phase by probe sonication for $10 \mathrm{~min}$. The mixture was transferred to a round-bottomed flask. The organic solvent was evaporated under reduced pressure with a rotary evaporator to form a gel. Subsequently, $30 \mathrm{~mL}$ of phosphate-buffered solution was added to the gel, which was then probe-sonicated for an additional $25 \mathrm{~min}$. The as-prepared liposomes were stored at $4{ }^{\circ} \mathrm{C}$ for further study. 
131

132

\subsubsection{Morphology of the liposomes}

Transmission electron microscopy (JEM-2100, Japanese Electronics Co., Ltd., Tokyo, Japan) was employed to determine the microstructure of $\mathrm{C} 3 \mathrm{G}$ liposomes via negative staining method. A drop of this solution was placed on a Formvar-carbon-coated copper grid for 5 min and was then imaged ${ }^{37}$.

\subsubsection{Cell culture}

\subsubsection{Cell culture}

The Caco-2 cells (CBCAS, Shanghai, China) were maintained in minimum essential medium (MEM) (Hyclone Laboratories, Inc., USA) supplemented with $10 \%$ fetal bovine serum (FBS) Hyclone Laboratories, Inc., USA, penicillin (100 kU/L), and streptomycin $(100 \mathrm{~g} / \mathrm{L})$ at $37{ }^{\circ} \mathrm{C}$ under a $5 \% \quad \mathrm{CO}_{2}$ atmosphere in a humidified incubator ${ }^{38-40}$. After reaching $70 \%-80 \%$ confluence, the cells were subcultured and maintained with medium changes every $2-3$ days.

\subsubsection{2D cell culture}

centrifuged at $1000 \mathrm{rpm}$ for $5 \mathrm{~min}$. Isolated cells were seeded at 24- and 96-well plates according to the experimental design. The cells were then cultured using MEM supplemented with 10\% FBS (Gibco BRL Co., Ltd., USA) and 1\% antibiotics (100 $\mathrm{IU} / \mathrm{mL}$ penicillin, and $100 \mu \mathrm{g} / \mathrm{mL}$ streptomycin) and maintained at $37{ }^{\circ} \mathrm{C}$ in an atmosphere of $95 \%$ air with $5 \% \mathrm{CO}_{2}$. All the experiments were performed on logarithmically growing cells. Prepared cells were exposed to various C3G liposome concentrations $(0,0.05,0.10,0.15,0.20$, or $0.25 \mathrm{mg} / \mathrm{mL})$. 


\subsubsection{3D cell culture}

The 3D cell culture was carried out using the 3D cell culture hydrogel kit (Hangzhou Kevin Biotechnology Co., Ltd., Hangzhou, China) in accordance with the manufacturer's directions. The Caco-2 cells were isolated as previously described, and the cell suspension was mixed with the gel (vol:vol=1:1) and shaken slightly and rapidly on a vortex for $1 \mathrm{~s}$ and repeated 1-2 times. Subsequently, the gel-cell mixture was added to the well and incubated in the plate in an incubator at $37{ }^{\circ} \mathrm{C}$ for $5-10 \mathrm{~min}$. Lastly, the culture medium was added to the plate, and the plate was moved to the humidified incubator and maintained at $37{ }^{\circ} \mathrm{C}$ in an atmosphere with $5 \% \mathrm{CO}_{2}$. The medium was replaced every 1-2 days. All the experiments were performed on logarithmically growing cells.

\subsubsection{Cell morphology}

For documenting the morphology of Caco-2 cells in 3D culture condition, the cells were washed with PBS twice. Phase contrast images of the cells cultured in 3D conditions were observed using an inverted microscope (Nikon Eclipse Ti, Nikon, Tokyo, Japan) at different magnifications ${ }^{41}$.

Scanning electron microscopy was used to analyze the cell morphology in different cell culture models. The Caco- 2 cells $\left(1 \times 10^{5}\right)$ were seeded on glass slides placed in a 6-well plate for 2 days. Then, the samples were removed from culture wells, rinsed with PBS, and fixed with $2.5 \%$ glutaraldehyde for $8 \mathrm{~h}$ at $4{ }^{\circ} \mathrm{C}$. Subsequently, the samples were rinsed again and postfixed in osmium tetroxide for $1 \mathrm{~h}$ before being dehydrated in a series of graded ethanol solutions $(30 \%, 50 \%, 70 \%, 80 \%, 90 \%$, and 
205

206

207

208

209

210

211

212

213

214

215

$95 \%$ vol/vol). Final drying was performed by critical-point method. Finally, gold-coated specimens were examined by SEM (Hitachi, SU-8010, Tokyo, Japan) ${ }^{42}$.

\subsubsection{Cell viability}

Cell viability was determined by 2,5-diphenyl tetrazolium bromide (MTT) assay at $550 \mathrm{~nm}$ with a microplate reader (Tecan Co., Weymouth, UK) ${ }^{43}$. The cells were seeded in 96-well plates in a $100 \mu \mathrm{L}$ volume $\left(1 \times 10^{4}\right.$ per well $)$ and allowed to grow for $24 \mathrm{~h}$ before treatment with different concentrations of C3G liposomes for $24 \mathrm{~h}$. At the end of the experiments, $10 \mu \mathrm{L}$ of $5 \mu \mathrm{g} / \mathrm{mL}$ MTT was added to each well. The cells were then incubated at $37{ }^{\circ} \mathrm{C}$ for $4 \mathrm{~h}$. Formazan was solubilized in $150 \mu \mathrm{L}$ of dimethyl sulfoxide and measured at $550 \mathrm{~nm}$. The results were given as relative values to the negative control in percentage, whereas the positive control was set to be $100 \%$ viable. The percentage of cell proliferation was calculated as ${ }^{44}$ :

$$
\text { Cell viability }(\%)=\frac{A_{\text {exp }} A_{n e g}}{A_{c o n-} A_{n e g}},
$$

where $A_{\exp }$ is the amount of experimental group absorbance, $A_{n e g}$ is the amount of blank group absorbance, and $A_{c o n}$ is the amount of the control group absorbance.

\subsubsection{Assay of GSH and SOD activity}

The assay of GSH and SOD activities was detected by glutathione peroxidase assay kit and total superoxide dismutase assay kit according to the manufacturer's protocol (Nanjing Jiancheng Bioengineering Institute, China). The Caco-2 cells were cultured in a $25 \mathrm{~cm}^{2}$ culture flask and exposed to $\mathrm{C} 3 \mathrm{G}$ and $\mathrm{C} 3 \mathrm{G}$ liposomes for $12 \mathrm{~h}$. The cells were then collected through centrifugation at $400 \times g$ for $5 \mathrm{~min}$ at $4{ }^{\circ} \mathrm{C}$ and the supernatant was removed. The cell suspension was washed and centrifuged twice 
227 using ice-cold PBS to remove all traces of the medium. The cell pellet was sonicated

228 at $300 \mathrm{~W}$ for $10 \mathrm{~s}$ (three cycles) to obtain lysates, which were then centrifuged at

$22912,000 \mathrm{rpm}$ for $10 \mathrm{~min}$. Cell supernatants were finally assayed to measure GSH and

230 SOD activities ${ }^{45,46}$.

231 Exactly $600 \mu \mathrm{L}$ of the cell suspension, $150 \mu \mathrm{L}$ of the substrate solution, and 600

$232 \mu \mathrm{L}$ of the reaction buffer solution were transferred to a fresh tube. The standard group

233 included $25 \mu \mathrm{mol} / \mathrm{L}$ GSH dissolved in a GSH buffer solution. In the blank group,

234 GSH was replaced by PBS. A microplate reader estimated the absorbance at $405 \mathrm{~nm}$,

235 and protein content was measured using the Bradford method using bovine serum

236 albumin as the standard.

237 Exactly $20 \mu \mathrm{L}$ of the prepared sample, $200 \mu \mathrm{L}$ of the SOD working solution, 20

$238 \mu \mathrm{L}$ of the enzyme working solution, and $20 \mu \mathrm{L}$ of dilution buffer were added to each

239 well of a 96-well plate, and the mixture was mixed thoroughly. The plate was

240 incubated for $20 \mathrm{~min}$ at $37^{\circ} \mathrm{C}$, and a plate reader was used to detect the absorbance at

$241450 \mathrm{~nm}$.

\subsubsection{T-AOC assay and MDA assay}

The Caco- 2 cells were cultured in a $25 \mathrm{~cm}^{2}$ culture flask and exposed to $\mathrm{C} 3 \mathrm{G}$ and

C3G liposomes for $12 \mathrm{~h}$ and collected for the T-AOC and MDA level tests. The

T-AOC and MDA levels in Caco-2 cells were measured with T-AOC and MDA

247 the manufacturer's protocols ${ }^{47,48}$.

248 The Caco-2 cells were cultured in a $25 \mathrm{~cm}^{2}$ culture flask and exposed to $\mathrm{C} 3 \mathrm{G}$ and 
249

250

251

252

253

254

255

256

257

258

259

260

261

262

263

264

265

266

267

268

269

270

C3G liposomes for $12 \mathrm{~h}$. The cells were then collected through centrifugation at 400 $\times g$ for 5 min at $4{ }^{\circ} \mathrm{C}$ and the supernatant was removed. The cell suspension was washed and centrifuged twice using ice-cold PBS to remove all traces of the medium. The cell pellet was sonicated at $300 \mathrm{~W}$ for $10 \mathrm{~s}$ (three cycles) to obtain lysates, which were then centrifuged at $12,000 \mathrm{rpm}$ for $10 \mathrm{~min}$. Cell supernatants were finally assayed to measure the assay of T-AOC and MDA.

For the detected of T-AOC of cells, exactly $100 \mu \mathrm{L}$ of the cell suspension added the reagent and the samples were treated according the manufacturer's protocols. A microplate reader estimated the absorbance at $520 \mathrm{~nm}$, and protein content was measured using the Bradford method using bovine serum albumin as the standard.

For the detected of MDA, exactly $200 \mu \mathrm{L}$ of the cell suspension added the reagent and the samples were treated according the manufacturer's protocols. The plate was incubated for $20 \mathrm{~min}$ at $37{ }^{\circ} \mathrm{C}$, and a plate reader was used to detect the absorbance at $532 \mathrm{~nm}$.

\subsubsection{Statistical analysis}

All experiments were performed thrice in duplicate per sample. Data are presented as the means \pm standard deviations from at least three independent measurements. Statistical analysis was performed using SPSS version 21.0 for Windows.

\section{Results}

\subsection{Characterization studies}

Transmission electron microscopy (TEM) was used to investigate the 
271

272

273

274

275

276

277

278

279

280

281

282

283

284

285

286

287

288

289

290

291

292

293

294

morphology of C3G liposomes. Figure 1 shows a recorded representative TEM image of C3G liposomes. The nanoparticles exhibited spherical shapes, and the size of C3G liposomes was approximately $200 \mathrm{~nm}$ and formed a vesicular structure. From our previous study ${ }^{36}$,the average diameter of $\mathrm{C} 3 \mathrm{G}$ liposomes is $165.78 \pm 4.3 \mathrm{~nm}$, the encapsulation efficiency of $\mathrm{C} 3 \mathrm{G}$ liposomes is $70.43 \% \pm 1.95 \%$.

\subsection{Cell morphology}

In our work, Caco-2 cells were cultured in the 3D models for 7 days and washed with PBS thrice. Subsequently, cell morphology was observed at different magnifications using an inverted microscope and scanning electron microscope.

As shown in Fig.2 and Fig.3, the morphology of the cell culture in the 3D model was different from the cell culture in the $2 \mathrm{D}$ model. From Fig.2, at different magnifications, the cells showed a mass-like spheroid growth, and the cells gathered and grew together. From the scanning electron microscope image, the Caco- 2 cells grew together in patches in the $2 \mathrm{D}$ culture. However, when grown in the $3 \mathrm{D}$ cell culture model, they formed uniform spheroids with relatively smooth surfaces. The SEM image showed that the Caco-2 cell culture in the 3D culture model formed a 3D structure and tight spheroids.

\subsection{Cell viability}

In this study, Caco-2 cells cultured in 2D and 3D models were treated with $\mathrm{C} 3 \mathrm{G}$ and C3G liposomes. Then, the cell viability was detected by MTT assay. The result is shown in Fig.4.

As shown in Fig. 4, the MTT assay results demonstrated a concentration-dependent activity after exposure to $\mathrm{C} 3 \mathrm{G}$ and $\mathrm{C} 3 \mathrm{G}$ liposomes in different cell culture models. From Fig. 4A, the cells in different culture models 
exhibit different cell activities after being exposed to C3G. In the 3D culture model, the cell activity is higher than that cultured in the $2 \mathrm{D}$ culture model. $\mathrm{IC}_{50}$ of cells exposed to $\mathrm{C} 3 \mathrm{G}$ in the $2 \mathrm{D}$ and $3 \mathrm{D}$ cell culture models are 0.19 and $0.25 \mathrm{mg} / \mathrm{mL}$, and 0.175 and $0.233 \mathrm{mg} / \mathrm{mL}$ when exposed to $\mathrm{C} 3 \mathrm{G}$ liposomes in different culture models, respectively. Figure 4B shows that the activity of cells exposed to $\mathrm{C} 3 \mathrm{G}$ liposomes and cells cultured in the $3 \mathrm{D}$ culture model is higher than the cells cultured in the $2 \mathrm{D}$ culture model. Cells cultured in the 3D culture model show higher cell activity and $\mathrm{IC}_{50}$ compared with the $2 \mathrm{D}$ cell culture model in this study. This phenomenon is due to multicellular resistance and the adhesion between cells, thereby reducing the sensibility of Caco-2 cells to the $\mathrm{C} 3 \mathrm{G}$ and $\mathrm{C} 3 \mathrm{G}$ liposomes ${ }^{49,50}$. At the same time, collagen gels purported to represent well in vivo conditions possibly causes the strong increase of cell viability.

\subsection{Assay of GSH activity in different cell culture models}

To compare the difference of GSH activity in different cell culture models, the Caco-2 cells cultured in the $2 \mathrm{D}$ and $3 \mathrm{D}$ culture models were treated with $\mathrm{H}_{2} \mathrm{O}_{2}(0.2 \mathrm{mmol}), \mathrm{C} 3 \mathrm{G}$, and $\mathrm{C} 3 \mathrm{G}$ liposomes for $12 \mathrm{~h}$, and the GSH activity was tested. Figure 5 shows the GSH activity in the 2D and 3D cell models. From Fig. 5, the GSH activity in different cell culture models is significantly different $(p<0.05)$. The $\mathrm{C} 3 \mathrm{G}$ and $\mathrm{C} 3 \mathrm{G}$ liposomes both can enhance the GSH activity treated with $\mathrm{H}_{2} \mathrm{O}_{2}$, and the enhancement in the 3D model is higher than that in the 2D model. At the same time, the enhancement of $\mathrm{C} 3 \mathrm{G}$ liposome is higher than that of $\mathrm{C} 3 \mathrm{G}$. This phenomenon is because the liposomes protect the $\mathrm{C} 3 \mathrm{G}$ from the effect of external environment factors, leading to the high effectiveness of cells and multicellular resistance, and the adhesion between cells reduces the sensibility of Caco-2 cells to the $\mathrm{C} 3 \mathrm{G}$ and $\mathrm{C} 3 \mathrm{G}$ liposomes ${ }^{49}$, 50. 


\subsection{Assay of SOD activity in different cell culture models}

To compare the difference of SOD activity in the $2 \mathrm{D}$ and $3 \mathrm{D}$ culture models, the Caco-2 cells cultured in the 2D and 3D culture models were treated with $\mathrm{H}_{2} \mathrm{O}_{2}(0.2 \mathrm{mmol}), \mathrm{C} 3 \mathrm{G}$, and $\mathrm{C} 3 \mathrm{G}$ liposomes for $12 \mathrm{~h}$, and the SOD activity was tested. Fig. 6 shows the SOD activity in the 2D and 3D cell models, and the SOD activity in different cell culture models is significantly different $(p<0.05)$. The $\mathrm{C} 3 \mathrm{G}$ and $\mathrm{C} 3 \mathrm{G}$ liposomes both can enhance the SOD activity treated with $\mathrm{H}_{2} \mathrm{O}_{2}$, and the enhancement in the $3 \mathrm{D}$ model is higher than that in the $2 \mathrm{D}$ model. At the same time, the enhancement of $\mathrm{C} 3 \mathrm{G}$ liposome is higher than that in $\mathrm{C} 3 \mathrm{G}$.

\subsection{Assay of MDA in different cell culture models}

To compare the difference of MDA content in different cell culture models, the Caco- 2 cells in different culture models were treated with $\mathrm{H}_{2} \mathrm{O}_{2}(0.2 \mathrm{mmol}), \mathrm{C} 3 \mathrm{G}$, and C3G liposomes for $12 \mathrm{~h}$, and the GSH activity was tested. Figure 7 shows the MDA content in the $2 \mathrm{D}$ and $3 \mathrm{D}$ cell models, and the result indicated that $\mathrm{H}_{2} \mathrm{O}_{2}$ can increase the MDA content after treatment. The $\mathrm{C} 3 \mathrm{G}$ and $\mathrm{C} 3 \mathrm{G}$ liposomes both can decrease the MDA content in different cell culture models. As for the reduced effect, the $\mathrm{C} 3 \mathrm{G}$ liposomes are higher than $\mathrm{C} 3 \mathrm{G}$. The result showed that $\mathrm{C} 3 \mathrm{G}$ and $\mathrm{C} 3 \mathrm{G}$ liposomes both can decrease the MDA content in different cell culture models and the reduced effect. The $\mathrm{C} 3 \mathrm{G}$ liposomes are higher than $\mathrm{C} 3 \mathrm{G}$. This phenomenon is because the liposomes protect the $\mathrm{C} 3 \mathrm{G}$ from the effect of external environment factors, leading to the high effectiveness of cells in different culture models.

\subsection{Assay of T-AOC in different cell culture models}


347 liposomes both can enhance the assay of T-AOC treated with $\mathrm{H}_{2} \mathrm{O}_{2}$, and the enhancement in the 3D model is higher than that in the 2D model. At the same time, the enhancement of $\mathrm{C} 3 \mathrm{G}$ liposome is higher than that of $\mathrm{C} 3 \mathrm{G}$.

The result indicated that the $\mathrm{C} 3 \mathrm{G}$ and $\mathrm{C} 3 \mathrm{G}$ liposomes can enhance the $\mathrm{T}-\mathrm{AOC}$ assay and then play an antioxidant role in Caco-2 cells.

\section{DISCUSSION}

In this study, we compared the antioxidant activity of $\mathrm{C} 3 \mathrm{G}$ and $\mathrm{C} 3 \mathrm{G}$ liposomes in different cell culture models. The cell were treat with $\mathrm{H}_{2} \mathrm{O}_{2}$ and incubated with the increase the concentration of GSH, improve the activity of SOD and T-AOC, the content of MDA were decreased after treated. In the 3D cell culture model, the effect is more obvious than cells cultured in 2D model.

$\mathrm{C} 3 \mathrm{G}$ is a potent antioxidant that displays anticancer properties in vitro and in vivo $^{51,52}$. However, few studies have evaluated the antioxidant properties of $\mathrm{C} 3 \mathrm{G}$ and C3G liposomes in the 3D cell culture model. The results of this study revealed that 
364

365

366

367

368

369

370

371

372

373

374

375

376

377

378

379

work did not focus on the molecular level of $\mathrm{C} 3 \mathrm{G}$ and $\mathrm{C} 3 \mathrm{G}$ liposomes to study the antioxidant activity of Caco-2 cells. Several studies have investigated the antioxidant activity of $\mathrm{C} 3 \mathrm{G}$ on cells at the molecular level. Thus, further studies on the antioxidant activity of C3G liposomes on cells at the molecular level are needed.

At the same time, the $3 \mathrm{D}$ cell culture model was developed as a new in vitro model. The cells cultured in 3D model exhibit features that are close to the complex in vivo conditions ${ }^{31}$ and have been proven realistic for translating the study findings for in vivo applications. In our work, we used hydrogel and built the $3 \mathrm{D}$ cell culture model. This method is inconvenient and time consuming. Thus, in future studies, we will use other materials (type I collagen matrix, 3D scaffolds) to construct the 3D cell culture model and compare the differences in different 3D cell culture models. Meanwhile, as for the $\mathrm{C} 3 \mathrm{G}$ liposome, a small size of $\mathrm{C} 3 \mathrm{G}$ liposomes is expected, making them more effective than $\mathrm{C} 3 \mathrm{G}$. At the same time, the uniform particle size is needed,which can improve the stability of liposomes, because the liposomes were used as carriers, the size is smaller, and they are more effective. The new method, which is uninjurious for liposome preparation, is important in our further studies.

Therefore, we need a new 3D cell culture model to explore the antioxidant mechanisms of $\mathrm{C} 3 \mathrm{G}$ and $\mathrm{C} 3 \mathrm{G}$ liposomes at the molecular level in the $3 \mathrm{D}$ cell culture model. Meanwhile, the properties, expression of specific genes, and protein effects, and mechanisms of $\mathrm{C} 3 \mathrm{G}$ liposomes on cells will be explored in further studies, another cells will used to build the 3D cell culture model and study the properties of C3G liposomes in future study is needed. 


\section{CONCLUSIONS}

In summary, the mechanism of C3G and C3G liposomes on cells in different cell culture models are as follows. The $\mathrm{C} 3 \mathrm{G}$ liposomes and $\mathrm{C} 3 \mathrm{G}$ can inhibit cell proliferation. The inhibiting effect of $\mathrm{C} 3 \mathrm{G}$ liposomes is higher than that of $\mathrm{C} 3 \mathrm{G}$. In the $3 \mathrm{D}$ cell culture model, the inhibiting effect is lower than that in the $2 \mathrm{D}$ cell culture model because in 3D conditions, the multicellular resistance and the adhesion between cells reduce the sensibility of Caco-2 cells to the $\mathrm{C} 3 \mathrm{G}$ and $\mathrm{C} 3 \mathrm{G}$ liposomes. Assay of GSH, SOD, MDA, and T-AOC demonstrated that the $\mathrm{C} 3 \mathrm{G}$ and $\mathrm{C} 3 \mathrm{G}$ liposomes can enhance the activities of GSH, SOD, and T-AOC and decrease the MDA content in different cell culture models. At the same time, in the 3D cell culture model, these results are more obvious than that in the 2D cell culture model.

\section{Competing interests}

The Author(s) declare(s) that they have no conflicts of interest to disclose.

\section{Acknowledgements}

This work was supported by Zhejiang Provincial Key Laboratory of Biometrology and Inspection and Quarantine, and National \& Local United Engineering Lab of Quality Controlling Technology and Instrumentation for Marine Food. We gratefully acknowledge financial support from National Natural Science Foundation of China (31571845), National Key R\&D Program of China ( grant No.2016YFD0401503), The Key Research and Development Program of Zhejiang province (2018C02049).

\section{Abbreviations}

C3G Cyanidin-3-O-glucoside

Caco-2 cells Human epithelial colorectal adenocarcinoma cells 

aCC-BY-NC 4.0 International license.

409 MEM Minimum essential medium

410 FBS Fetal Bovine Serum

411 PC Phosphatidylcholine

$412 \mathrm{CH} \quad$ Cholesterol

413 TEM Transmission electron microscope

414 SEM Scanning electron microscope

$4152 \mathrm{D} \quad$ Two-dimensional

416 3D Three-dimensional

417

418

419

420

421

422

423

424

425

426

427

428

429

430 


\section{References}

1. P. Jing, B. Qian, S. Zhao, X. Qi, L. Ye, M. Monica Giusti and X. Wang, Effect of glycosylation patterns of Chinese eggplant anthocyanins and other derivatives on antioxidant effectiveness in human colon cell lines, Food Chem, 2015, 172, 183-189. composite systems for anthocya nin stabilization, Food Hydrocolloids, 2018, 81, 371-379.

3. L. Yi, C.-y. Chen, X. Jin, M.-t. Mi, B. Yu, H. Chang, W.-h. Ling and T. Zhang, Structural requirements of anthocyanins in relation to inhibition of endothelial injury induced by

4. R. Cuevas, iacute, E. O. guez, V. P. Dia, G. G. Yousef, P. A. Garcia-Saucedo and J. Lopez-Medina,

5. A. Sousa, P. Araújo, J. Azevedo, L. Cruz, I. Fernandes, N. Mateus and V. de Freitas, Antioxidant and antiproliferative properties of 3-deoxyanthocyanidins, Food Chem, 2016, 192, 142-148.

7. M.-M. Ma, Y. Li, X.-Y. Liu, W.-W. Zhu, X. Ren, G.-Q. Kong, X. Huang, L.-P. Wang, L.-Q. Luo and

8. H. Cai, B. Yang, Z. Xu, B. Zhang, B. Xu, X. Li, P. Wu, K. Chen, R. V. Rajotte, Y. Wu and G. R. Rayat,

9. P. Pratheeshkumar, Y. O. Son, X. Wang, S. P. Divya, B. Joseph, J. A. Hitron, L. Wang, D. Kim, Y. Yin, R. V. Roy, J. Lu, Z. Zhang, Y. Wang and X. Shi, Cyanidin-3-glucoside inhibits UVB-induced oxidative damage and inflammation by regulating MAP kinase and NF-kappaB signaling pathways in SKH-1 hairless mice skin, Toxicology and applied pharmacology, 2014, 280, 127-137.

P. H. Shih, C. T. Yeh and G. C. Yen, Effects of anthocyanidin on the inhibition of proliferation 
and induction of apoptosis in human gastric adenocarcinoma cells, food and chemical toxicology : an international journal published for the British Industrial Biological Research Association, 2005, 43, 1557-1566.

11. J. S. Lee, Y. R. Kim, J. M. Park, Y. E. Kim, N. I. Baek and E. K. Hong, Cyanidin-3-glucoside isolated from mulberry fruits protects pancreatic beta-cells against glucotoxicity-induced apoptosis, Molecular medicine reports, 2015, 11, 2723-2728.

12. X. Yan, L. Wu, B. Li, X. Meng, H. Dai, Y. Zheng and J. Fu, Cyanidin-3-O-glucoside Induces Apoptosis and Inhibits Migration of Tumor Necrosis Factor- $\alpha$-Treated Rat Aortic Smooth Muscle Cells, Cardiovascular Toxicology, 2016, 16, 251-259.

13. D. Liu, F. Pan, J. Liu, Y. Wang, T. Zhang, E. Wang and J. Liu, Individual and combined antioxidant effects of ginsenoside F2 and cyanidin-3-O-glucoside in human embryonic kidney 293 cells, RSC Adv., 2016, 6, 81092-81100.

14. X. Yan, L. Wu, B. Li, X. Meng, H. Dai, Y. Zheng and J. Fu, Cyanidin-3-O-glucoside Induces Apoptosis and Inhibits Migration of Tumor Necrosis Factor-alpha-Treated Rat Aortic Smooth Muscle Cells, Cardiovasc Toxicol, 2015, DOI: 10.1007/s12012-015-9333-z.

15. N. Priego, M. Arechederra, C. Sequera, P. Bragado, A. Vázquezcarballo, Á. Gutiérrezuzquiza, V. Martíngranado, J. J. Ventura, M. G. Kazanietz and C. Guerrero, C3G knock-down enhances migration and invasion by increasing Rap1-mediated p38 $\alpha$ activation, while it impairs tumor growth through p38 $\alpha$-independent mechanisms, Oncotarget, 2016, 7, 45060-45078.

16. A. D. Bangham, M. W. Hill and N. G. A. Miller, in Methods in Membrane Biology: Volume 1, ed. E. D. Korn, Springer US, Boston, MA, 1974, DOI: 10.1007/978-1-4615-7422-4_1, pp. 1-68.

17. N. A. Lopes, C. M. B. Pinilla and A. Brandelli, Pectin and polygalacturonic acid-coated liposomes as novel delivery system for nisin: Preparation, characterization and release behavior, Food Hydrocolloids, 2017, 70, 1-7.

18. R. Guan, J. Ma, Y. Wu, F. Lu, C. Xiao, H. Jiang and T. Kang, Development and characterization of lactoferrin nanoliposome: cellular uptake and stability, Nanoscale Research Letters, 2012, 7, 679.

19. M. Guan, Y. Zhou, Q.-L. Zhu, Y. Liu, Y.-Y. Bei, X.-N. Zhang and Q. Zhang, N-trimethyl chitosan nanoparticle-encapsulated lactosyl-norcantharidin for liver cancer therapy with high targeting efficacy, Nanomedicine: Nanotechnology, Biology and Medicine, 2012, 8, 1172-1181.

20. L. Zou, S. Peng, W. Liu, X. Chen and C. Liu, A novel delivery system dextran sulfate coated amphiphilic chitosan derivatives-based nanoliposome: Capacity to improve in vitro digestion stability of (-)epigallocatechin gallate, Food Research International, 2015, 69, 114-120.

21. Y.-W. Noh, S.-Y. Kim, J.-E. Kim, S. Kim, J. Ryu, I. Kim, E. Lee, S. H. Um and Y. T. Lim, Multifaceted Immunomodulatory Nanoliposomes: Reshaping Tumors into Vaccines for Enhanced Cancer Immunotherapy, Advanced Functional Materials, 2017, 27, 1605398.

22. D. W. Hutmacher, Biomaterials offer cancer research the third dimension, Nat Mater, 2010, 9, 90-93.

23. H. Page, P. Flood and E. G. Reynaud, Three-dimensional tissue cultures: current trends and beyond, Cell Tissue Res, 2013, 352, 123-131.

24. N. Anastasov, I. Hofig, V. Radulovic, S. Strobel, M. Salomon, J. Lichtenberg, I. Rothenaigner, K. Hadian, J. M. Kelm, C. Thirion and M. J. Atkinson, A 3D-microtissue-based phenotypic screening of radiation resistant tumor cells with synchronized chemotherapeutic treatment, BMC Cancer, 2015, 15, 466. 
512

513

514

515

516

517

518

519

520

521

522

523

524

525

526

527

528

529

530

531

532

533

534

535

536

537

538

539

540

541

542

543

544

545

546

547

548

549

550

551

552

553

554

555
25. J. G. Moffat, J. Rudolph and D. Bailey, Phenotypic screening in cancer drug discovery - past, present and future, Nat Rev Drug Discov, 2014, 13, 588-602.

26. J. A. Hickman, R. Graeser, R. de Hoogt, S. Vidic, C. Brito, M. Gutekunst, H. van der Kuip and I. P. consortium, Three-dimensional models of cancer for pharmacology and cancer cell biology: Capturing tumor complexity in vitro/ex vivo, Biotechnology Journal, 2014, 9, 1115-1128.

27. J. M. Kelm, N. E. Timmins, C. J. Brown, M. Fussenegger and L. K. Nielsen, Method for generation of homogeneous multicellular tumor spheroids applicable to a wide variety of cell types, Biotechnol Bioeng, 2003, 83, 173-180.

28. E. Cukierman, R. Pankov, D. R. Stevens and K. M. Yamada, Taking Cell-Matrix Adhesions to the Third Dimension, Science, 2001, 294, 1708.

29. M. Ravi, A. Ramesh and A. Pattabhi, Contributions of 3D Cell Cultures for Cancer Research, J Cell Physiol, 2016, DOI: 10.1002/jcp.25664.

30. G. Y. Lee, P. A. Kenny, E. H. Lee and M. J. Bissell, Three-dimensional culture models of normal and malignant breast epithelial cells, Nat Methods, 2007, 4.

31. M. Vinci, S. Gowan, F. Boxall, L. Patterson, M. Zimmermann, W. Court, C. Lomas, M. Mendiola, D. Hardisson and S. A. Eccles, Advances in establishment and analysis of three-dimensional tumor spheroid-based functional assays for target validation and drug evaluation, $B M C$ Biology, 2012, 10, 29.

32. M. Ravi, V. Paramesh, S. R. Kaviya, E. Anuradha and F. D. Solomon, 3D cell culture systems: advantages and applications, J Cell Physiol, 2015, 230, 16-26.

33. S. Breslin and L. O'Driscoll, The relevance of using 3D cell cultures, in addition to 2D monolayer cultures, when evaluating breast cancer drug sensitivity and resistance, Oncotarget, 2016, 7, 45745-45756.

34. N. Falkenberg, I. Hofig, M. Rosemann, J. Szumielewski, S. Richter, K. Schorpp, K. Hadian, M. Aubele, M. J. Atkinson and N. Anastasov, Three-dimensional microtissues essentially contribute to preclinical validations of therapeutic targets in breast cancer, Cancer Med, 2016, 5, 703-710.

35. X. Luo, R. Guan, X. Chen, M. Tao, J. Ma and J. Zhao, Optimization on condition of epigallocatechin-3-gallate (EGCG) nanoliposomes by response surface methodology and cellular uptake studies in Caco-2 cells, Nanoscale Res Lett, 2014, 9, 291.

36. T. Liang, R. Guan, H. Shen, Q. Xia and M. Liu, Optimization of Conditions for Cyanidin-3-OGlucoside (C3G) Nanoliposome Production by Response Surface Methodology and Cellular Uptake Studies in Caco-2 Cells, Molecules, 2017, 22, 457.

37. E. Arab Tehrany, C. J. Kahn, C. Baravian, B. Maherani, N. Belhaj, X. Wang and M. Linder, Elaboration and characterization of nanoliposome made of soya; rapeseed and salmon lecithins: application to cell culture, Colloids and surfaces. B, Biointerfaces, 2012, 95, 75-81.

38. E. Roka, Z. Ujhelyi, M. Deli, A. Bocsik, E. Fenyvesi, L. Szente, F. Fenyvesi, M. Vecsernyes, J. Varadi, P. Feher, R. Gesztelyi, C. Felix, F. Perret and I. K. Bacskay, Evaluation of the Cytotoxicity of alpha-Cyclodextrin Derivatives on the Caco-2 Cell Line and Human Erythrocytes, Molecules, 2015, 20, 20269-20285.

39. F. Bonnier, M. E. Keating, T. P. Wrobel, K. Majzner, M. Baranska, A. Garcia-Munoz, A. Blanco and $H$. J. Byrne, Cell viability assessment using the Alamar blue assay: a comparison of 2D and 3D cell culture models, Toxicology in vitro : an international journal published in association with BIBRA, 2015, 29, 124-131. 
40. T. Kang, R. Guan, X. Chen, Y. Song, J. Han and J. Zhao, In vitro toxicity of different-sized ZnO nanoparticles in Caco-2 cells, Nanoscale Research Letters, 2013, 8, 496.

41. R. Guan, T. Kang, F. Lu, Z. Zhang, H. Shen and M. Liu, Cytotoxicity, oxidative stress, and genotoxicity in human hepatocyte and embryonic kidney cells exposed to ZnO nanoparticles, Nanoscale Res Lett, 2012, 7, 602.

42. P. Shi, A. Laude and W. Y. Yeong, Investigation of cell viability and morphology in 3D bio-printed alginate constructs with tunable stiffness, J Biomed Mater Res A, 2017, 105, 1009-1018.

43. Z. Xiao, Y. Zhang, X. Chen, Y. Wang, W. Chen, Q. Xu, P. Li and F. Ma, Extraction, identification, and antioxidant and anticancer tests of seven dihydrochalcones from Malus 'Red Splendor' fruit, Food Chem, 2017, 231, 324-331.

44. T. Kang, R. Guan, Y. Song, F. Lyu, X. Ye and H. Jiang, Cytotoxicity of zinc oxide nanoparticles and silver nanoparticles in human epithelial colorectal adenocarcinoma cells, LWT - Food Science and Technology, 2015, 60, 1143-1148.

45. T. Liang, R. Guan, M. Tao, F. Lyu, G. Cao, M. Liu and J. Gao, In Vitro Toxicity of Zinc Oxide Nanoparticles from Food Additives in Human Gastric Epithelium (GES-1) Cells, Science of Advanced Materials, 2017, 9, 1393-1400.

46. Y. Lin, H. Lin, S. Zhang, Y. Chen, M. Chen and Y. Lin, The role of active oxygen metabolism in hydrogen peroxide-induced pericarp browning of harvested longan fruit, Postharvest Biology and Technology, 2014, 96, 42-48.

47. Z. Gao, C. Zhang, W. Tian, K. Liu, R. Hou, C. Yue, Y. Wu, D. Wang, J. Liu, Y. Hu and Y. Yang, The antioxidative and hepatoprotective effects comparison of Chinese angelica polysaccharide(CAP)and selenizing CAP (SCAP) in $\mathrm{CCl} 4$ induced hepatic injury mice, International Journal of Biological Macromolecules, 2017, 97, 46-54.

48. H. Chen, H. Hu, D. Chen, J. Tang, B. Yu, J. Luo, J. He, Y. Luo, J. Yu and X. Mao, Dietary Pectic Oligosaccharide Administration Improves Growth Performance and Immunity in Weaned Pigs Infected by Rotavirus, J Agric Food Chem, 2017, DOI: 10.1021/acs.jafc.7b00039.

49. J. Sudimack and R. J. Lee, Targeted drug delivery via the folate receptor, Advanced Drug Delivery Reviews, 2000, 41, 147-162.

50. I. Mahapatra, J. Clark, P. J. Dobson, R. Owen and J. R. Lead, Potential environmental implications of nano-enabled medical applications: critical review, Environmental Science: Processes \& Impacts, 2013, 15, 123-144.

51. T. Liang, R. Guan, Z. Wang, H. Shen, Q. Xia and M. Liu, Comparison of anticancer activity and antioxidant activity between cyanidin-3-O-glucoside liposomes and cyanidin-3-0-glucoside in Caco-2 cells in vitro, RSC Advances, 2017, 7, 37359-37368.

52. P. Strugaå,A, A. Dudra and J. Gabrielska, Interaction between Mimic Lipid Membranes and Acylated and Nonacylated Cyanidin and Its Bioactivity, Journal of Agricultural \& Food Chemistry, 2016, 64, 7414-7422.

\section{Figure legends}

Fig. 1. Transmission Election Microscope (TEM) image of C3G nanoliposomes.

Fig. 2. Cell morphology of 3D culture cells in different magnification times. 
598 Fig.3. The cell morphology of 2D and 3D cell culture models(A:The cells culture in

599 2D cell culture model;B:The cells culture in 2D cell culture model that treated with

600 pancreatin ;C: The cells culture in 3D cell culture model.)

601 Fig.4. The cell viability of 2D and 3D culture cells expose to C3G and C3G liposomes

602 (A:The cell treated with C3G;B:The cell treated with C3G liposomes.)

603 Fig.5. The concentration of GSH in different cell culture models

604 Fig. 6. The activity of SOD in different cell culture models

605 Fig. 7. The content of MDA in different cell culture models

606 Fig. 8. The strength of antioxidant capacity in different cell culture models

607

608

609

610

611

612

613

614

615

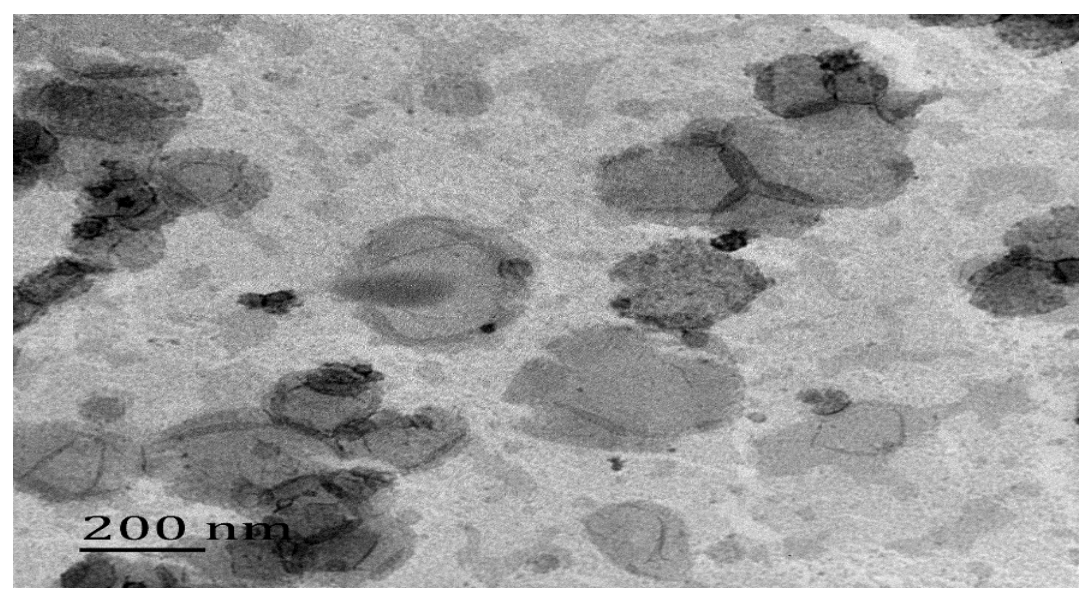

Figure.1

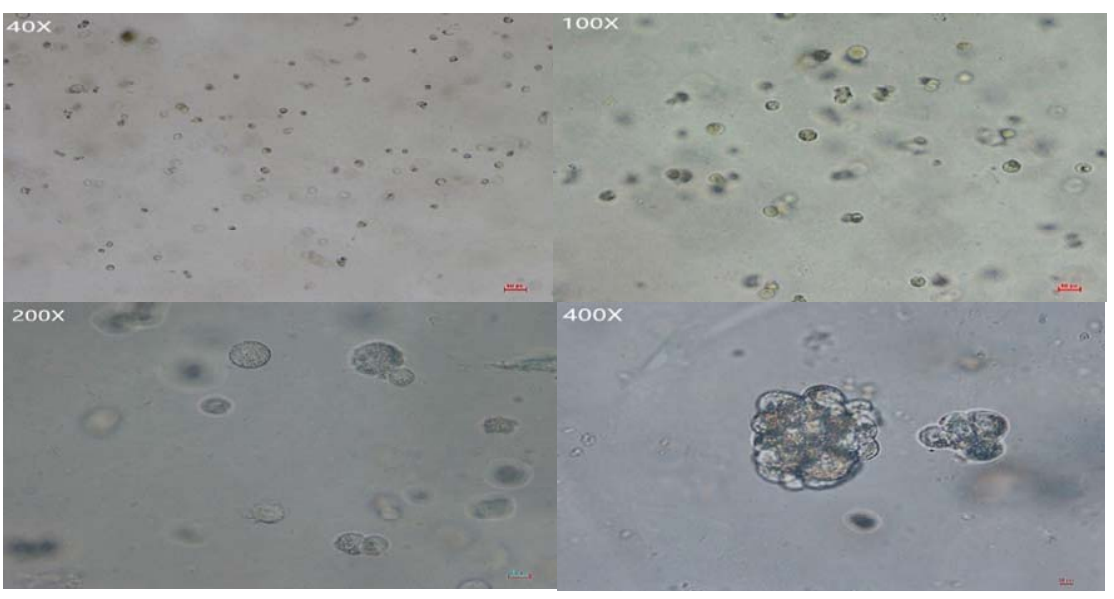

Figure.2 

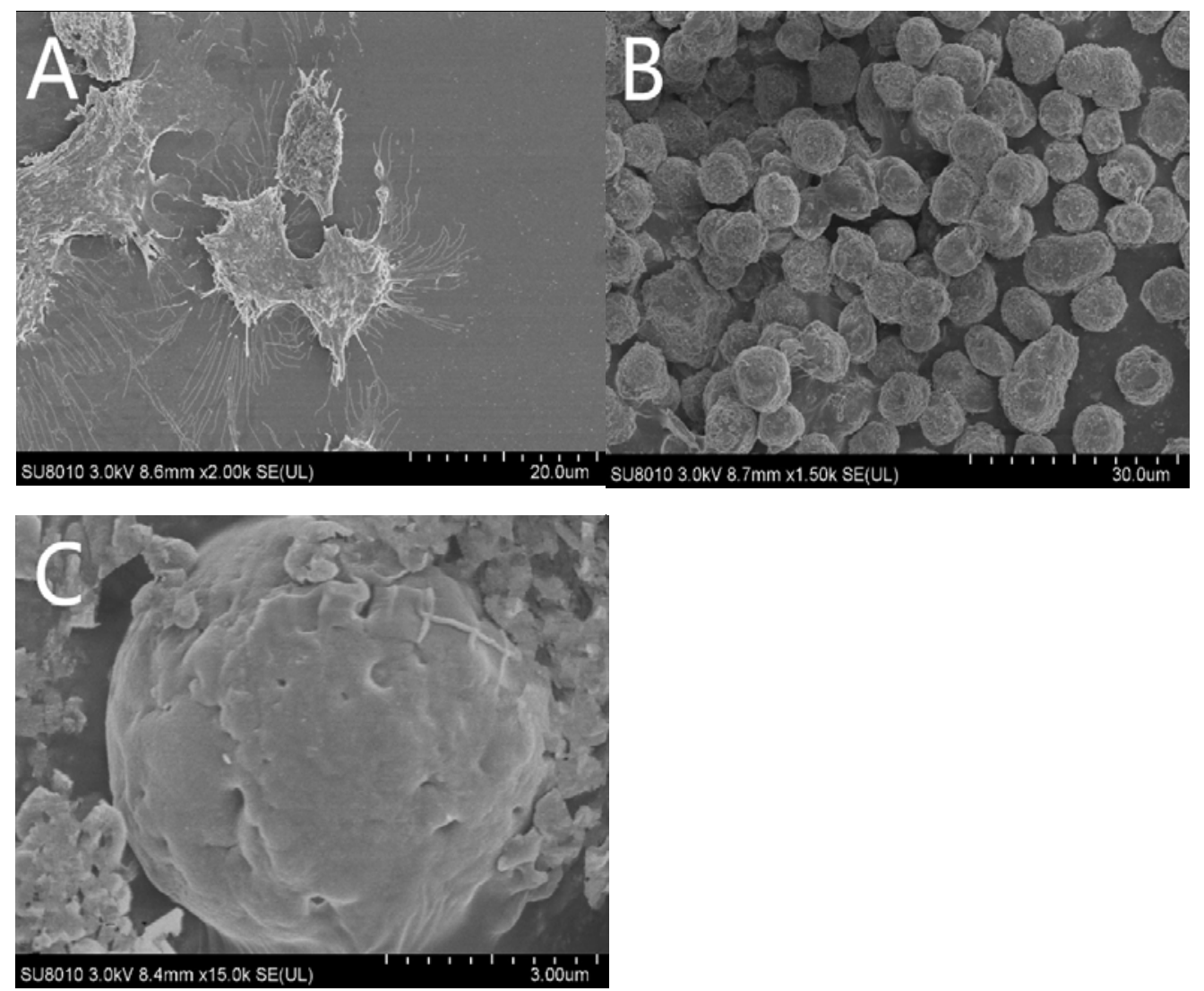

Figure.3

620
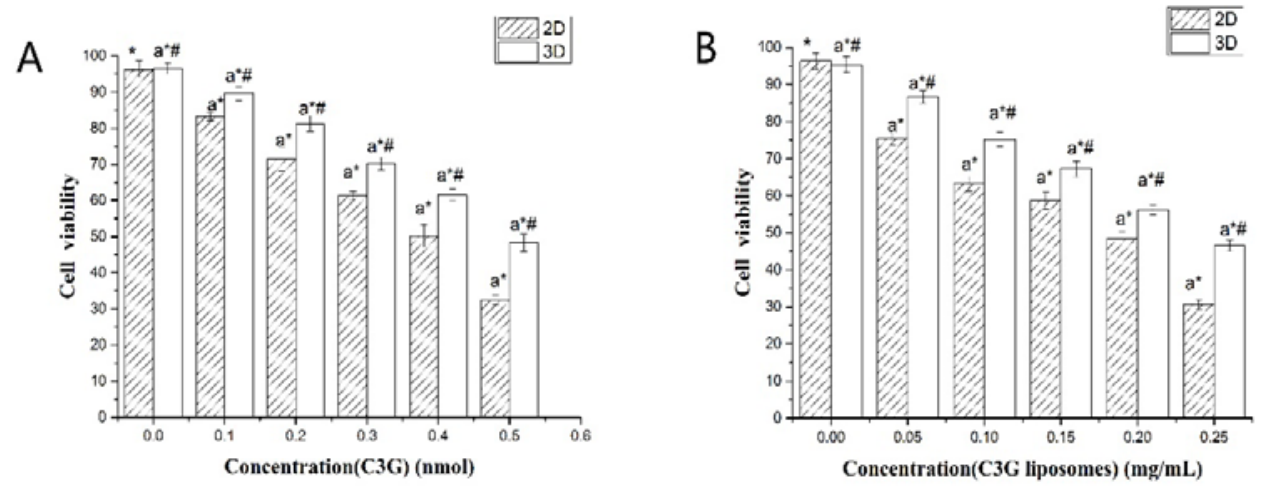

$621\left({ }^{*} p<0.05\right.$,compared with the control group ${ }_{,}^{\#} p<0.05$,compared with the $2 \mathrm{D}$ group, ${ }^{\mathrm{a}} p<0.05$, compared with the different dose group ) 


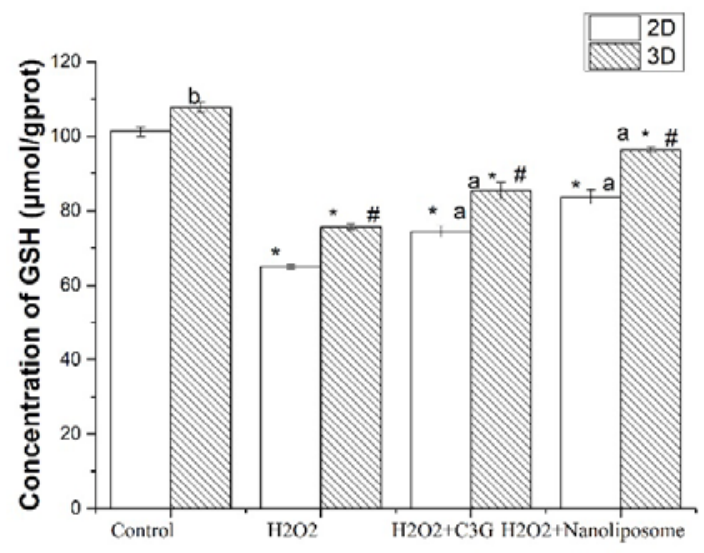

624

$625 \quad\left({ }^{*} p<0.05\right.$,compared with the control group ${ }^{\#} p<0.05$,compared with the $2 \mathrm{D}$ group, ${ }^{\mathrm{a}} p<0.05$,

626 compared with the $\mathrm{H}_{2} \mathrm{O}_{2}$ treated group, ${ }^{\mathrm{b}} p<0.05$, compared with the $2 \mathrm{D}$ group )

627

Figure.5

628

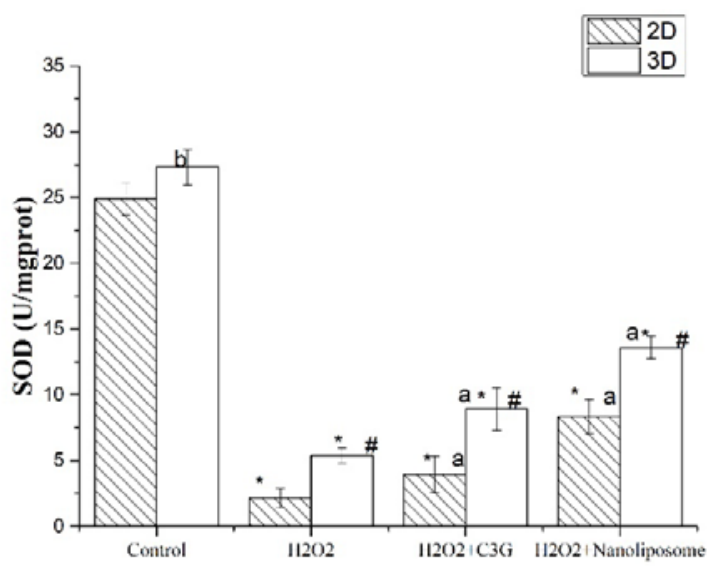

629

$630 \quad\left({ }^{*} p<0.05\right.$,compared with the control group ${ }^{\#} p<0.05$,compared with the $2 \mathrm{D}$ group, ${ }^{\mathrm{a}} p<0.05$,

631 compared with the $\mathrm{H}_{2} \mathrm{O}_{2}$ treated group, ${ }^{\mathrm{b}} p<0.05$, compared with the 2D group ) 


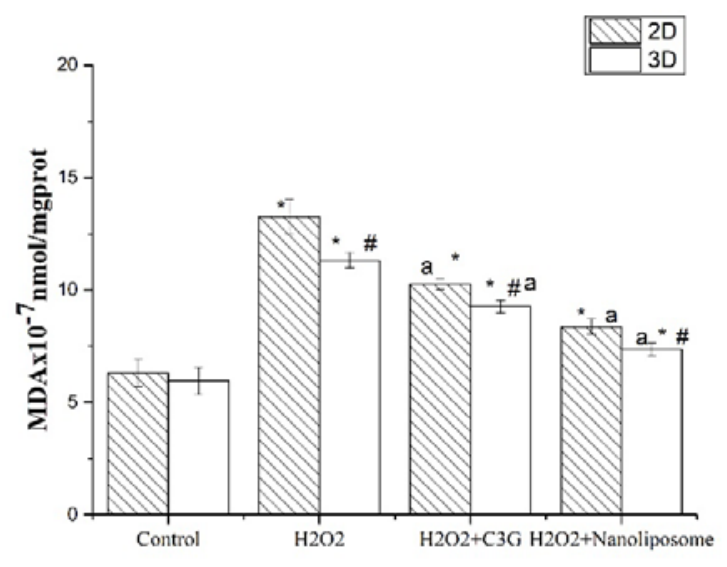

633

$634 \quad\left({ }^{*} p<0.05\right.$,compared with the control group ${ }^{\#} p<0.05$,compared with the $2 \mathrm{D}$ group, ${ }^{\mathrm{a}} p<0.05$, 635 compared with the $\mathrm{H}_{2} \mathrm{O}_{2}$ treated group )

636

Figure.7

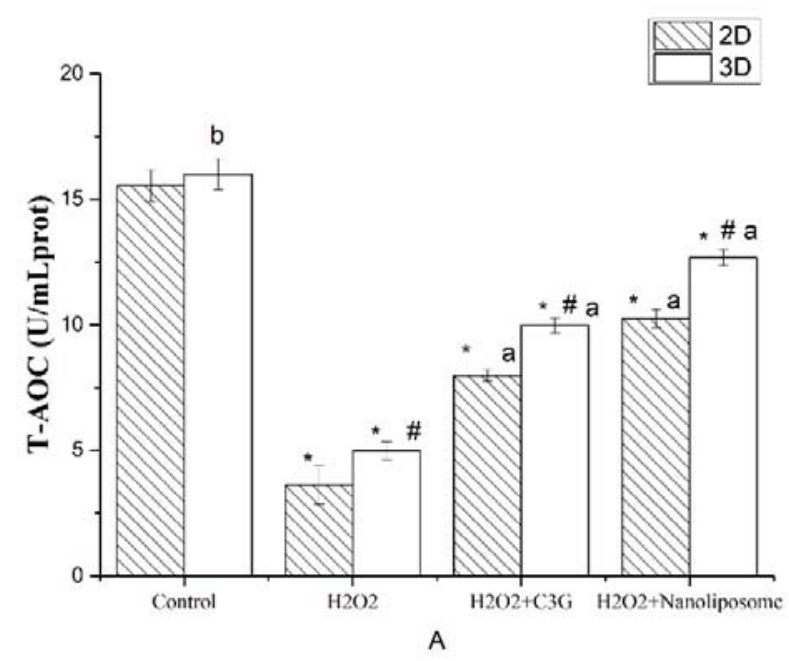

637

$638 \quad\left({ }^{*} p<0.05\right.$,compared with the control group ${ }^{\#} p<0.05$,compared with the $2 \mathrm{D}$ group, ${ }^{\mathrm{a}} p<0.05$,

639 compared with the $\mathrm{H}_{2} \mathrm{O}_{2}$ treated group, ${ }^{\mathrm{b}} p<0.05$, compared with the $2 \mathrm{D}$ group ) 